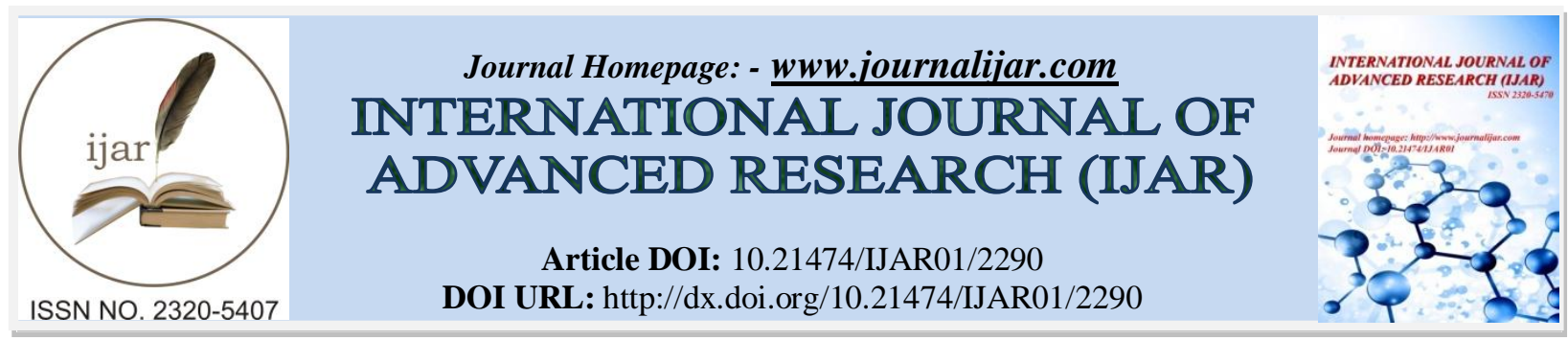

RESEARCH ARTICLE

\title{
EFFECT OF TREATED WASTE WATER ON RAPID CHLORIDE ION PERMEABILITY OF M25 GRADE CONCRETE.
}

\section{Vivek Thakur ${ }^{1}$ and Dr. Hemant Sood ${ }^{2}$.}

1. M.E. Scholar, Civil Engineering, NITTTR Chandigarh, India.

2. Professor and H.O.D, Civil Department, NITTTR Chandigarh, India.

\section{Manuscript Info}

Manuscript History

Received: 29 September 2016

Final Accepted: 30 October 2016

Published: November 2016

Key words:-

Treated waste water (TWW), Chloride ion, Ordinary Portland cement (OPC), Potable water (PW), Rapid chloride ion permeability (RCPT).

\section{Abstract}

Among the variety of factors which influence the durability of concrete structures, chloride ions ingress is one of the governing factors enhancing the corrosion and reducing the durability at a faster rate. With the continuous infiltration of $\mathrm{Cl}^{-}$ions the passivating layer that protects the concrete is disturbed rendering it more vulnerable to corrosive effects. In this research the effect of using treated waste water on chloride ion permeability of M25 grade concrete is studied. For optimizing the use of treated waste water cube specimens were cast using variable proportions of treated waste water and potable water such as: $50 \%, 75 \%, 100 \%$ and comparison was done with potable water results. Out of the various proportions of treated waste water and potable water used, for M25 grade concrete $75 \% \mathrm{TWW}$ exhibited superior RCPT result.

Copy Right, IJAR, 2016,. All rights reserved.

\section{Introduction:-}

Being aware of the fact that none of the advancements in the technological field can guarantee human survival until and unless we save the environment we live in, whole of the world is united to save the environment and its resources. Every year a dozen of summits, conferences and meets are organized at national as well as international levels to bring awareness about saving our environment but a very little effect is seen.

Water is the basic unit of life, which in the time to come needs to be conserved. Construction industry is biggest consumer sector of potable water with tremendous rate of consumption. We can change the basic ingredients, especially water so that our motive of saving potable water is fulfilled without disturbing the construction activities.

Waste water can be the new alternative for potable water, which many of us would not agree to use but a significant amount of research has been carried out and presented in this paper which is enough to consider this hard believing fact. Without compromising the durability aspect of concrete structure we can use the waste water instead of potable water. The only prerequisite is that the water to be used should satisfy a certain set of chemical properties as defined by BIS: 3025. Hence, any water lying within the given agreed limits can be used undoubtedly in production of concrete. 


\section{Materials and Methodology:-}

Cement: - Ultra-tech OPC 43 grade conforming to BIS: 8112 was used for this research work.

Water: - The sewage treatment plant located at 3BRD Chandigarh was selected as suitable source of treated waste water used in this research work. Laboratory tests for various chemical properties were conducted as per BIS: 3025 in the institute's laboratory. The results are as shown in the table 1.

Table 1:- Chemical Properties of Treated Waste Water

\begin{tabular}{|c|l|c|c|c|}
\hline S. No. & \multicolumn{1}{|c|}{ Parameters } & $\begin{array}{c}\text { Potable Water } \\
(\mathbf{m g} / \mathbf{l} \text { or } \mathbf{~ m})\end{array}$ & $\begin{array}{c}\text { Treated Waste Water } \\
(\mathbf{m g} / \mathbf{l} \text { or } \mathbf{~ m l})\end{array}$ & $\begin{array}{c}\text { Permissible Limits } \\
(\mathbf{m g} / \mathbf{l} \text { or } \mathbf{~ m})\end{array}$ \\
\hline 1 & pH & 7.49 & 7.24 & $>6$ \\
\hline 2 & DO & 7.38 & 6.83 & - \\
\hline 3 & COD & 10 & 196 & 3000 \\
\hline 4 & BOD & 6 & 140 & 200 \\
\hline 5 & TDS & 225 & 532 & 400 \\
\hline 6 & Sulphate Content & 24.72 & 36.3 & 2000 \\
\hline 7 & Chloride Content & 18.5 & 140 & 5 \\
\hline 8 & Acidity & - & 3.5 & 25 \\
\hline 9 & Alkalinity & 11.5 & - & 200 \\
\hline
\end{tabular}

Coarse aggregate:- Aggregate having Specific gravity 2.74 conforming to BIS: $383-1970$ was used in this project. Maximum size aggregate limited to $20 \mathrm{~mm}$ was mixed with $12 \mathrm{~mm}$ sized aggregate in proportion of 1.5:1 in order to make a well graded mix.

Fine aggregate: - Locally available clean river sand having specific gravity value 2.65 conforming to zone III was used.

Mix Design: - Mix design for M25 grade was carried out as per BIS: 10262-2009.

Casting: - For carrying out rapid chloride ion permeability test (RCPT) a set of three cylinders $(100 \mathrm{~mm} \times 200 \mathrm{~mm})$ for each water proportion were cast. The various waste water proportions used were as such:

a) $100 \%$ treated waste water.

b) $75 \%$ treated waste water with $25 \%$ potable water.

c) $50 \%$ treated waste water with $50 \%$ potable water.

d) $100 \%$ potable.

Curing: - Curing for variable days was done in the water tank filled with potable water maintained at $28 \pm 3^{0} \mathrm{C}$.

Rapid chloride ion permeability test: - This test method covers the determination of the electrical conductance of concrete to present a rapid indication of its resistance to the penetration of chloride ions. The test procedure followed was as per ASTM 1202. The cylindrical specimens $50 \mathrm{~mm}$ thick and $100 \mathrm{~mm}$ diameter were prepared, coated with epoxy on the outer surface (to ensure uni-directional flow of electrons) and then placed in vacuum desiccator for 3 hours after which they were allowed to soak in the distilled water for another 16 hours. The specimens were then wiped surface dry and fitted within the cell assembly for another 6 hours. The arrangement of the whole RCPT apparatus and prepared specimens is as shown in the below given figure 1, 2 and 3. 


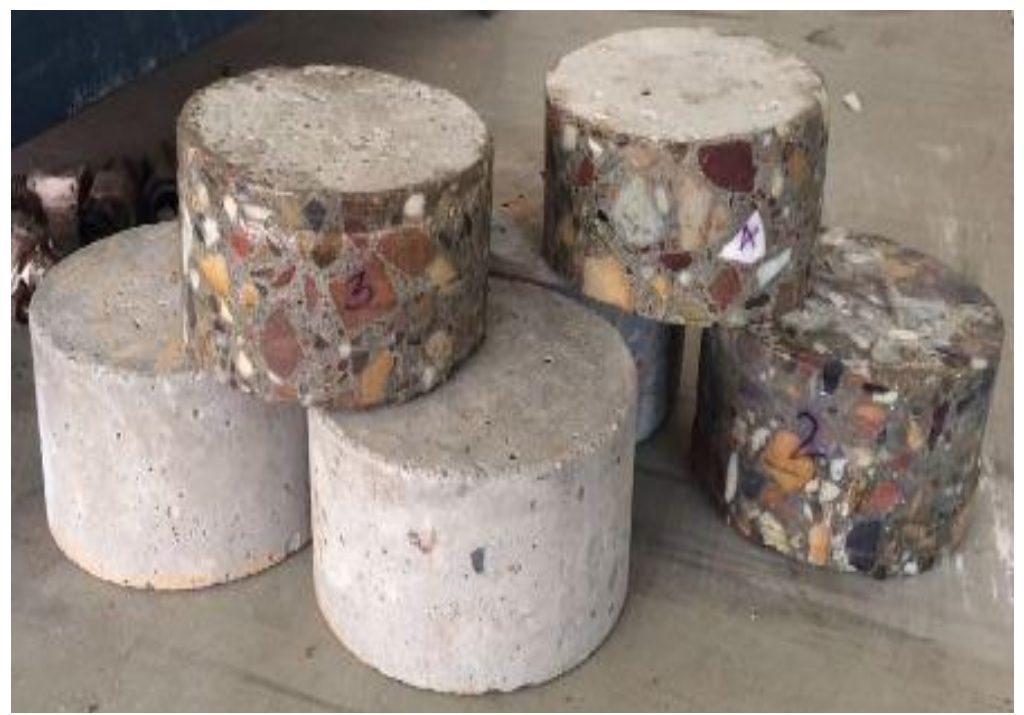

Figure 1:- Test specimens.

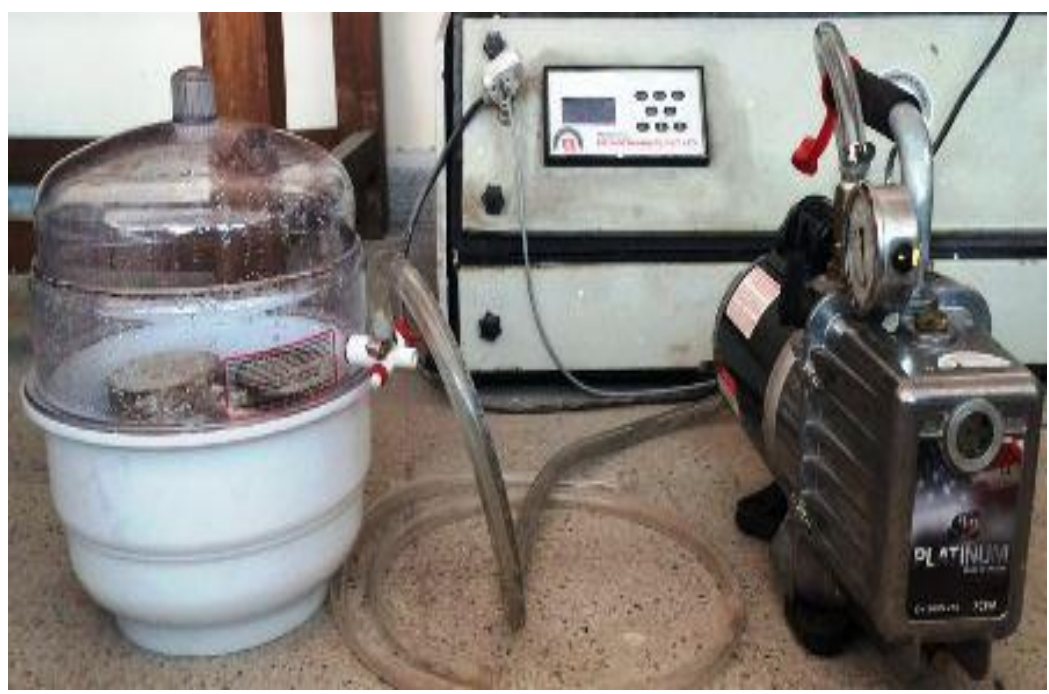

Figure 2:- Vacuum desiccator

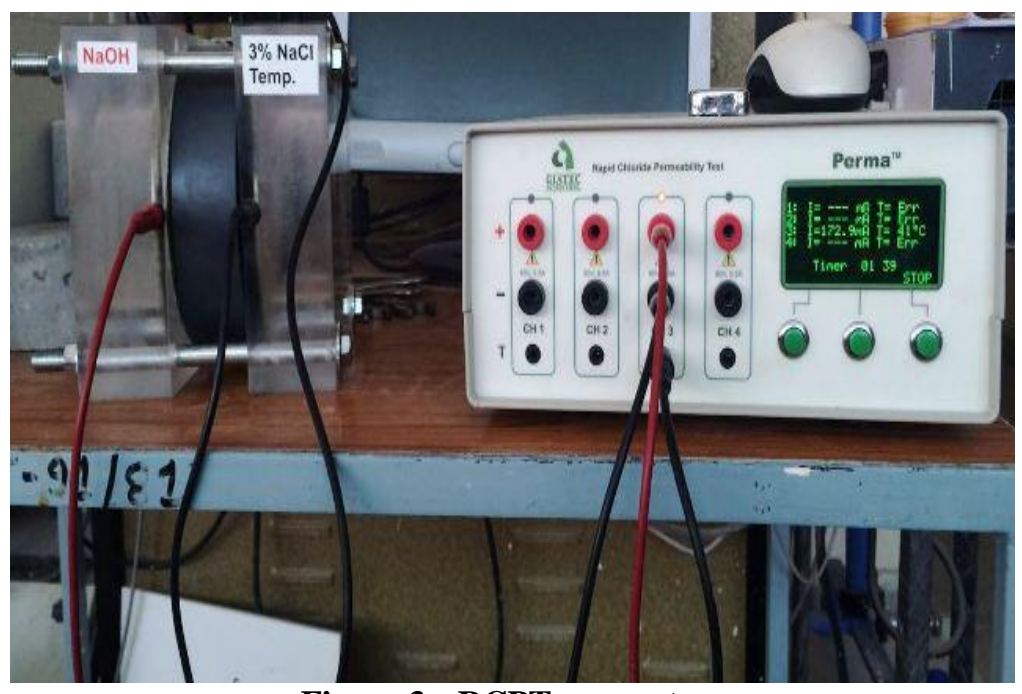

Figure 3:- RCPT apparatus 
After the completion of test the value of total charge passed was shown on the instrument's main screen. This value was then be compared with the values given in the standard table 2

Table 2:- Rating of chloride ion permeability of concrete according to RCPT

\begin{tabular}{|c|c|}
\hline Chloride ion penetration & $\begin{array}{c}\text { 56-day Rapid chloride permeability charge passed } \\
\text { (Coulombs) }\end{array}$ \\
\hline High & $>4000$ \\
\hline Moderate & $2000-4000$ \\
\hline Low & $1000-2000$ \\
\hline Very low & $100-1000$ \\
\hline Negligible & $<100$ \\
\hline
\end{tabular}

\section{Results:-}

M25 Grade concrete:-

The value of total charge passed as evaluated with the help of RCPT apparatus at 28 days curing for various proportions of treated waste water and potable water is depicted in the figure 4.

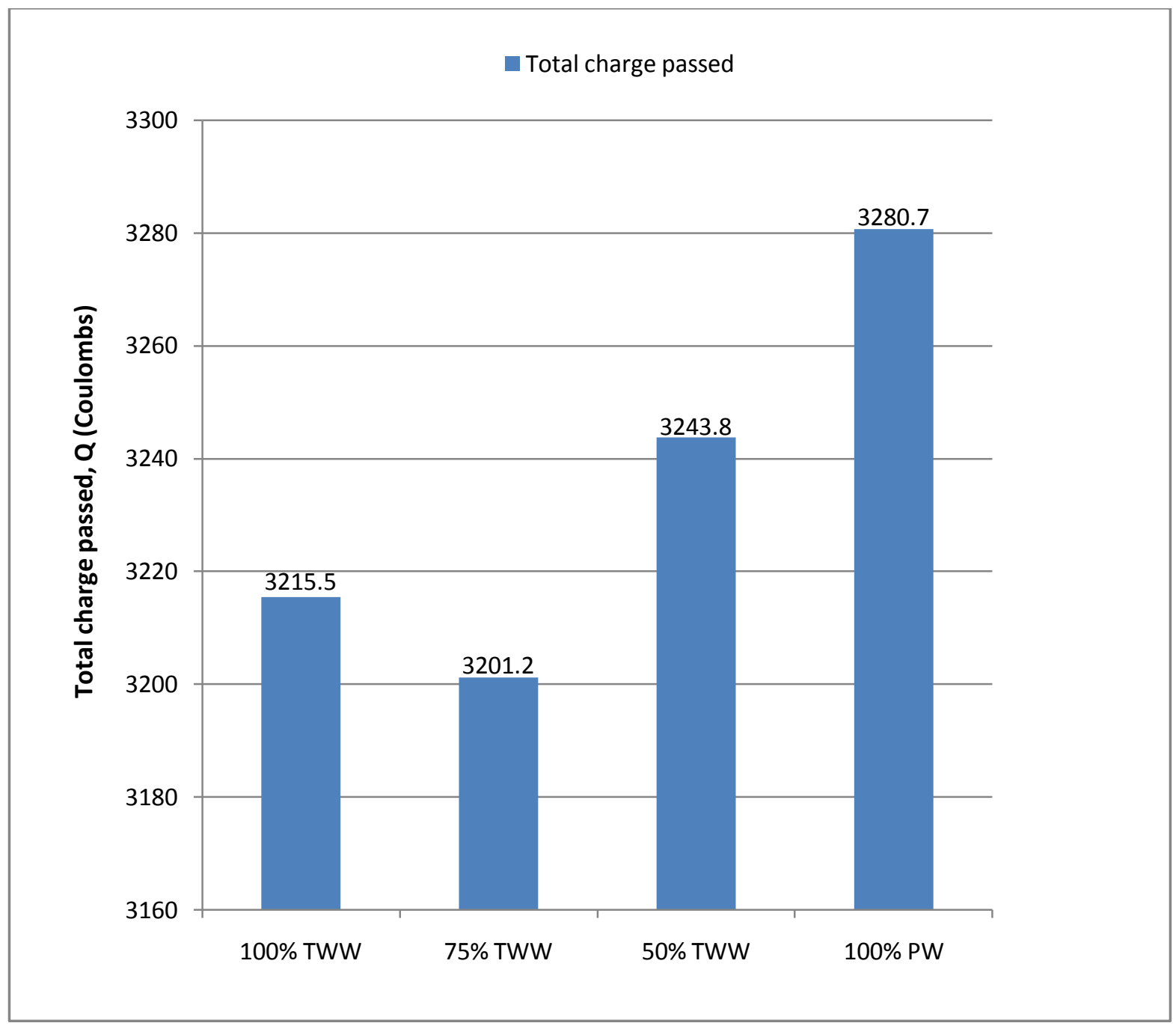

Figure 4:- Total charge passed for M25 grade concrete

We can observe that for M25 grade concrete, 75\% TWW results are satisfactory. The table 3 presents the combined RCPT results for various treated waste water proportions. 
Table 3:- Results for rapid chloride ion permeability test

\begin{tabular}{|c|c|c|c|}
\hline S.No & $\begin{array}{c}\text { Proportioning of } \\
\text { TWW }\end{array}$ & $\begin{array}{c}\text { 28-day Charge passed (Coulombs) } \\
\text { For M25 Grade Concrete }\end{array}$ & Inference \\
\cline { 3 - 4 } & $50 \% \mathrm{TWW}$ & 3243.8 & Moderate \\
\hline 1. & $75 \% \mathrm{TWW}$ & 3201.2 & Moderate \\
\hline 2. & $100 \% \mathrm{TWW}$ & 3215.5 & Moderate \\
\hline 3. & $100 \% \mathrm{PW}$ & 3280.7 & Moderate \\
\hline 4. & \multicolumn{2}{c}{} \\
\hline
\end{tabular}

Summary of the test Results:-

We can monitor that for M25 grade concrete, RCPT result corresponding to $75 \% \mathrm{TWW}$ is satisfactory.

\section{Conclusions:-}

1. M25 grade concrete cast with 75\% TWW and 25\% PW exhibit the lowest RCPT value.

2. By examining the overall results we can figure out that the value of total charge passed corresponding to $100 \%$ TWW is also quite satisfying.

\section{Acknowledgement:-}

This study acknowledges the support of Public Health Department of Municipal Corporation and Sewage Treatment Plant, 3BRD, Chandigarh of their support.

\section{References:-}

1. Karthikeyan M; Asha B; "Experimental Analysis of Regenerate the Treated Wastewater in Concrete", International Journal of World Research, Vol. 1, Issue 4, April 2014.

2. Mahasneh B. Z; "Assessment of Replacing Wastewater and Treated Water with Tap Water in Making Concrete Mix”, Electronic Journal of Geotechnical Engineering, Vol. 19, pp. 2379-2386, 2014.

3. Tamilarasan S; Perumal P; Maheswaran J; "Experimental Study On Water Permeability And Chloride Permeability Of Concrete With GGBS as a Replacement Material For Cement", International Journal Of Civil Engineering And Technology, Vol.3, Issue 2, July-December 2012.

4. Chandramouli K; Srinivasa Rao P; Seshadri Sekhar T; Pannirselvam N; Sravana P; "Rapid Chloride Permeability Test For Durability Studies On Glass Fibre Reinforced Concrete", ARPN Journal of Engineering and Applied Sciences, Vol. 5, March 2010.

5. K. Nirmal Kumar; V. Siva Kumar; "A study on the durability impact of concrete by using recycled waste water", Journal of Industrial Pollution Control, Vol. 24, pp. 1-6, 2008.

6. Scott; Alexander; "The Influence Of Binder Type, Cracking And Cover On Corrosion Rates Of Steel In Chloride-Contaminated Concrete", Magazine of Concrete Research, pp. 495-505, 2007.

7. Vagelis Papadakis; "Effect Of Supplementary Cementing Materials On Concrete Resistance Against Carbonation And Chloride Ingress", Cement and Concrete Research, Jan.2000.

8. Shi C; Stegemann J; Caldwell R; "Effect of Supplementary Cementing Materials on the Specific Conductivity of Pore Solution and Its Implications on the Rapid Chloride Permeability Test Results," (AASHTO T277 and ASTM C 1202) July-August 1998.

9. Cabrera G; Claisse P; Hunt N; "A Statistical Analysis Of The Factors Which Contribute To The Corrosion Of Steel In Portland Cement And Silica Fume Concrete", Construction and Building Materials, Vol.9, No.2, pp.105-113, 1995.

10. Bureau of Indian Standards plain and Reinforced Concrete Code of Practice, BIS: 456-2000.

11. Bureau of Indian Standards Recommended Guidelines for Concrete Mix Design, BIS: 10262-2009. 